\title{
Inhibition of granulocyte migration by tiotropium bromide
}

\author{
Gabriela Vacca ${ }^{1}$, Winfried J Randerath ${ }^{2 *}$, Adrian Gillissen ${ }^{3}$
}

\begin{abstract}
Study objectives: Neutrophil influx into the airways is an important mechanism in the pathophysiology of the inflammatory process in the airways of patients with chronic obstructive pulmonary disease (COPD). Previously it was shown that anticholinergic drugs reduce the release of non-neuronal paracrine mediators, which modulate inflammation in the airways. On this basis, we investigated the ability of the long-acting anticholinergic tiotropium bromide to inhibit a) alveolar macrophage (AM)-mediated chemotaxis of neutrophils, and b) cellular release of reactive oxygen species (ROS).
\end{abstract}

Method: AM and neutrophils were collected from 71 COPD patients. Nanomolar concentrations of tiotropium bromide were tested in AM cultured up to $20 \mathrm{~h}$ with LPS $(1 \mu \mathrm{g} / \mathrm{ml})$. AM supernatant was tested for TNF $\alpha, I L 8, I L 6$, LTB4, GM-CSF, MIP $\alpha / \beta$ and ROS. It was further used in a 96-well chemotaxis chamber to stimulate the migration of fluorescence labelled neutrophils. Control stimulants consisted of acetylcholine (ACh), carbachol, muscarine or oxotremorine and in part PMA (phorbol myristate acetate, $0.1 \mathrm{\mu g} / \mathrm{ml}$ ). Potential contribution of $\mathrm{M}_{1-3}$-receptors was ascertained by a) analysis of mRNA transcription by RT-PCR, and b) co-incubation with selective M-receptor inhibitors.

Results: Supernatant from AM stimulated with LPS induced neutrophilic migration which could be reduced by tiotropium in a dose dependent manner: $22.1 \pm 10.2$ ( $3 \mathrm{nM}), 26.5 \pm 18,4(30 \mathrm{nM})$, and $37.8 \pm 24.0$ (300 nM, p < 0.001 compared to non-LPS activated AM). Concomitantly TNF $\alpha$ release of stimulated AM dropped by $19.2 \pm 7.2 \%$ of control $(p=0.001)$. Tiotropium bromide did not affect cellular IL8, IL6, LTB4, GM-CSF and MIP $\alpha / \beta$ release in this setting. Tiotropium (30 nM) reduced ROS release of LPS stimulated AM by $36.1 \pm 15.2 \%(p=0.002)$ and in carbachol stimulated AM by $46.2 \pm 30.2$ ( $p<0.001$ ). M3R gene expression dominated over M2R and M1R. Chemotaxis inhibitory effect of tiotropium bromide was mainly driven by M3R inhibition.

Conclusion: Our data confirm that inhibiting muscarinic cholinergic receptors with tiotropium bromide reduces TNF $\alpha$ mediated chemotactic properties and ROS release of human AM, and thus may contribute to lessen cellular inflammation.

\section{Introduction}

The pathogenesis of chronic obstructive pulmonary disease (COPD) is characterized by persistent neutrophilic inflammation of the airways and lung parenchyma [1,2]. They release cytokines, leukotrienes, reactive oxygen species (ROS), elastases and other proinflammatory mediators which correlate broadly with disease severity [3-5]. Neutrophils are attracted from the capillary bed

\footnotetext{
* Correspondence: randerath@klinik-bethanien.de

²Department for Pulmonary Medicine, Allergology, Sleep Medicine and Intensive Care, Hospital Bethanien, Universitaet Witten/Herdecke, Solingen, Germany

Full list of author information is available at the end of the article
}

into the airways through chemotactic mechanisms which are intensified during exacerbation [6,7]. With increasing disease severity activated mononuclear cells and monocytes/macrophages contribute more and more to the complex inflammatory process in the airways and in the bronchial submucosa of those patients [8].

Chemotaxis is a biological phenomenon whereby a cell type migrates through barriers (e.g. vessel walls, epithelial layers or tissue) toward the site of inflammation. These cells will initiate and maintain the inflammatory process through a variety of mechanisms including ROS release. In COPD, chemotaxis is not only regarded as an important pathologic feature of prolonged inflammation

\section{Biomed Central}


due to cigarette smoke inhalation, but may also be an appealing target for anti-inflammatory therapy. By reducing the neutrophil influx into the airways one should be able to reduce the burden of airway inflammation and, thus, change the natural history of the disease $[9,10]$. Unfortunately, inhaled corticosteroids have been shown to reduce neutrophilic inflammation in COPD patients just poorly at best [11-13]. Long-acting $\beta 2$ agonists do not have intrinsic anti-inflammatory properties per se. In contrast, the long-acting muscarinic receptor antagonist tiotropium bromide has been shown a) to regulate release of chemotactic factors from human epithelial cells and macrophages in vitro [14], b) to inhibit airway remodelling and increase in smooth muscle mass in ovalbumin-sensitised guinea pigs $[15,16]$, and c) to inhibit acetylcholine mediated proliferation of fibroblasts and myofibroblasts in vitro $[17,18]$. These observations may be based on induced mitogenesis by stimulated muscarinic receptors and mediator release, which can be lessened by muscarinic receptor antagonists [19].

We hypothesize that tiotropium may have potential antiinflammatory properties helping to explain its good clinical efficacy e.g. the reduction of exacerbation rate which can hardly be related to its bronchodilative function alone. Through reducing chemotaxis of neutrophils via inhibition pro-chemotactic properties of alveolar macrophages anticholinergic drugs and tiotropium in particular may impact the neutrophil and macrophage driven inflammation in COPD in a considerable way. This would be a new perspective how those compounds affect those patients. The rationale for this study was therefore to test tiotropium having anti-chemotatic properties in a macrophage and neutrophil containing cell system.

\section{Methods}

In this study alveolar macrophages and neutrophils from COPD patients $(n=71)$ were used. They were recruited during out-patient or in-patient visits in our institution. Main inclusion criteria were a smoking history of $\geq 20$ pack-years, COPD regardless of severity according GOLD -criteria (global initiative for lung disease [20]). Main exclusion criteria were an acute infection of the airways or the lung, other chronic lung diseases (except COPD), cancer or extra-pulmonary chronic diseases causing clinical instability. All patients gave written, informed consent. All of them had a clinical history, a physical examination and an X-ray from the chest prior to bronchoscopy and bronchoalveolar lavage (BAL). Appropriate investigations relating to the clinical presentation together with history including smoking history, spirometric and radiologic data as well as blood gas analysis were obtained from the records. The study was approved by the ethics committee of the Saxonian Chamber of Physicians, Dresden, Germany (approval No.: EK-BR-27/05-2).

Patients referred for bronchoscopy for various clinical reasons were invited to participate in the study. Prior to bronchoscopy short acting anticholinergic drugs (ipratropium bromide) were stopped for at least $12 \mathrm{~h}$ and the long acting tiotropium bromide for at least $48 \mathrm{~h}$. Prednisolone was limited to $7,5 \mathrm{mg} /$ day. Inhaled shortand long-acting $\beta 2$-agonists, inhaled corticosteroids, further, antibiotics and theophylline were allowed.

BAL was performed according to standard procedure as recommended $[21,22]$. The bronchoscope was wedged in the right middle lobe or lingula and up to $140 \mathrm{ml}$ of normal warmed $\left(37^{\circ} \mathrm{C}\right)$ saline was instilled in 20 -ml aliquots. Lavage fluid was immediately rinsed through gauze in order to remove surplus mucus. The fluid was centrifuged at $800 \mathrm{rpm}$ for 10 minutes, $1 \times 10^{6} / \mathrm{ml}$ isolated macrophages were plated on 24-well tissue culture plates in RPMI (Biochrom AG)/10\%FCS/L-glutamine (2 mM, GIBCO/Invitrogen)/antibiotics (penicillin $100 \mathrm{IU} / \mathrm{ml}$, streptomycin $100 \mu \mathrm{g} / \mathrm{ml}$, amphotericin $0,25 \mathrm{mg} / \mathrm{ml}$, Biochrom AG) and cultured up to $2 \mathrm{~h}$ at $37^{\circ} \mathrm{C} / 5 \% \mathrm{CO} 2$. After washing to remove unattached AM and other cells, cells were further cultured over night. For estimation of cell viability/ cytotoxicity we used trypan blue and neutral red uptake assay as described elsewhere [23]. Viability had to be $\geq 90 \%$, macrophage content of BAL cell differential $\geq 85 \%$, and at least 5 million cells were all required for further analysis. Cell vitality and cellular purity (microscopic examination of 300 cells at magnification $\times 100$ ) was always $\geq 95 \%$. For all experiments a cellular concentration of $2 \times 10^{6}$ cells $/ \mathrm{ml}$ was used. All experiments were run in triplicates.

Polymorphonuclear leukocytes were isolated from the blood of these patients according to standard procedure as described elsewhere [24]. They were labelled with Calcein AM $(5 \mu \mathrm{g} / \mathrm{ml}$, Molecular Probes) in a $30 \mathrm{~min}$ incubation step at $37^{\circ} \mathrm{C} / 5 \% \mathrm{CO} 2$ for later detection using a flourescence based detection system. Neutrophils were than washed twice with PBS, counted and resuspended in RPMI/FCS/L-glutamine/penicillin/streptomycin/amphotericin $[25,26]$.

AM were washed and incubated at $37^{\circ} \mathrm{C} / 5 \% \mathrm{CO}_{2}$ for different time periods with RPMI/1\%FCS/L-glutamine/ penicillin/strepto-mycin/amphotericin with or without increasing concentrations of either acetylcholine (ACh: $1000 ; 100 ; 10 ; 1 ; 0.1 \mu \mathrm{M})$, carbachol, muscarin, oxotremorin $(100,10$ and $1 \mu \mathrm{M})$ or LPS $(10,1$ and $0.1 \mu \mathrm{g} / \mathrm{ml}$; all reagents from Sigma Chemicals). In addition costimulation was done with LPS $(0.1-1 \mu \mathrm{g} / \mathrm{ml})$ and carbachol or muscarin $(10-100 \mu \mathrm{M})$. After designated time periods, supernatants were strip off, centrifuged to remove remaining cells and cell detritus and frozen $\left(-80^{\circ} \mathrm{C}\right)$ for cytokine quantification. 
AM and neutrophils from these patients were prospectively distributed to the different assays. Due to large assay number and control experiments, as well as depending on the usefulness of the material and the cell number obtained from each patient, assays were run only with a certain proportion of patient samples: $\mathrm{n}=$ 20 for chemotaxis with tiotropium, $\mathrm{n}=10$ for LPS/carbachol/muscarin/tiotropium co-stimulation, $\mathrm{n}=9$ for controls with acetylcholin-esterase, $\mathrm{n}=15$ for RT-PCR experiments, $\mathrm{n}=17$ for ROS release experiments.

\section{Cytotoxicity}

After AM-stimulation with LPS with or without tiotropium ( $3 \mathrm{nM}, 30 \mathrm{nM}, 300 \mathrm{nM}$ ) for 4 and $20 \mathrm{~h}$, supernatants were stripped off. Remaining cells were washed three times with PBS and cytotoxicity was quantified. For the estimation of cell cytotoxicity we used neutral red uptake assay as described elsewhere [23]. Control cells (cultured with RPMI/1\%FCS/antibiotics/glutamine) were set to $100 \%$ and used for normalisation. Proper staining with 2',7'-dihydrodichlorofluorescein diacetate $\left(\mathrm{H}_{2}\right.$ DCFDA $)$ a fluorescent dye used in the cytotoxicity assay was confirmed by Fluorescence microscopy (Nikon).

\section{Chemotaxis}

Cell migration of neutrophils was assayed using a 96well Transwell chamber (pore diameter $3 \mu \mathrm{m}$, Corning). The bottom chamber was filled with culture supernatants generated from AM culture supernatant as described above. Isolated neutrophils $\left(75 \mu \mathrm{l}, 2 \times 10^{6}\right.$ cells) were placed in the upper chamber. Spontaneous migration during incubation in $37^{\circ} \mathrm{C} / 5 \% \mathrm{CO} 2$ for $60 \mathrm{~min}$. was determined using RPMI alone. RPMI/1\% FCS/L-glutamine/penicillin/strepto-mycin/amphotericin in the bottom chamber functioned as positive control (= FCS induced migration). Migrated cells were quantified in a multi-well fluorescent plate reader (Fluostar, BMG), whereas the intensity of the calcein fluorescence signal detected at excitation $485 \mathrm{~nm}$ and emission $535 \mathrm{~nm}$ in the bottom chamber corresponds to neutrophil cells found there. The values of the spontaneous migration were set to $100 \%$ and used for normalisation of different experiments.

Different muscarinic receptor antagonists were tested to elucidate the role of specific M-receptors and their inhibitors on chemotactic activity in AM cultured in RPMI/ FCS/L-glutamine/penicillin/streptomycin/amphotericin: telenzepine (M1R inhibitor, $0.01 \mu \mathrm{M})$, gallamine (M2R inhibitor, $100 \mu \mathrm{M}$ ), 4-DAMP (M3R inhibitor, $100 \mathrm{nM}$ ), tubocurarine (nicotinic receptor inhibitor, $100 \mu \mathrm{M})$, ipratropium (30 nM, Sigma Chemicals) and tiotropium (3 nM, 30 nM, 300 nM, provided by Boehringer Ingelheim).

\section{Cytokine measurements}

Commercially available ELISA kits were used for the detection of human IL-8, IL6, TNF alfa, GM-CSF (IBL, Hamburg, Germany), LTB 4 (Cayman, USA), MIP $\alpha / \beta$ (Biosource Int., USA) in AM supernatants with minor modifications of the manufacturer's protocol.

\section{Reactive oxygen species (ROS)}

Intracellular ROS formation was measured by the oxidant sensitive dye 2',7'-dichlorofluorescein diacetate (DCFH-DA [27]). The amount of fluorescence correlates with ROS released by the cells. AM were cultured under the above culture conditions (with or without the compounds to be tested), washed in PBS and then incubated with $1 \mu \mathrm{l}$ DCFH-DA/ $1 \mathrm{ml}$ PBS for $1 \mathrm{~h}$ at $37^{\circ} \mathrm{C} / 5 \% \mathrm{CO} 2$. Fluorescence was quantified with FLUOstar OPTIMA (BMG Labtech). Negative controls consisted of a) AM cultured without DCFH-DA, and b) AM preincubated with prednisolone $(10 \mu \mathrm{M})$. LPS activated AM and PMA $0.1 \mu \mathrm{g} / \mathrm{ml}$ were used as positive controls.

\section{RT-PCR}

For quantitative mRNA expression of muscarinic receptors of AM RT-PCR (Rotorgene 3000, Corbett Research) was used. Total RNA was isolated using Trizol (Invitrogen), quantified spectrophotometrically and $1 \mu \mathrm{g}$ was reverse transcribed to produce cDNA (Superspcript III Platinum, Invitrogen). The cDNA was then used to determine gene expression levels of the muscarinic receptors M1R-M3 relative to $\beta$-actin. The PCR reaction was performed with primers described by Pieper et al. [17]. The specificity of PCR reactions was verified by melting curve analyses and electrophoresis (date not shown). The primers used had the following sequences: M1R for (5'-GGCACGCTGGCTTGTGA-3'), M1R rev (5'-TTCATGACGGAGGCATTGC-3'), M1R-Probe (FAM-5'-CTGGCCCTGGACTATGTGGCC-3-TAM RA'), M2R-for (5'- CCTGGAGCACAACAAAATCCA -3'), M2R-rev (5' - TCCCTGAACACAGTTTTCAGTCA3'), M2R-Probe (FAM-5'-ATGGCAAAGCCCCCAGGG ATCC-3-TAMRA'), M3R-for (5'-ACAGCCCCTCCGATGCA -3'), M3R-rev (5'-AACATTGTAGCTGC CGAAATGA -3'), M3R-Probe (FAM-5'-CTGCCCCCGG GAACCGTC -3-TAMRA'), $\beta$-actin for (5'-TGACGCC GGCTACAGCTT -3'), $\beta$-actin rev (5'-TCCTTAATGTCACGCACGATTT -3'), $\beta$-actin-Probe (FAM-5' ACCACCACGGCCGAGCGG -3-TAMRA'). In order to exclude that our results were influenced by different muscarinic receptor expression due to varying culture conditions, RT-PCR was performed in AM-RNA a) without over night incubation ( $2 \mathrm{~h}$ after isolation from BAL), b) with overnight incubation in RPMI/10\%FCS/Lglutamine/penicillin/streptomycin/amphotericin (for 
$20 \mathrm{~h}$ ), c) in control cells (see above), and d) in AM stimulated with LPS $(1 \mu \mathrm{g} / \mathrm{ml})$ or e) carbachol $(100 \mu \mathrm{M})$.

\section{Statistical analysis}

Values were expressed as mean value \pm SD (or \pm SEM when indicated) of $n$ experiments. For statistical analysis to compare the response of $\mathrm{AM} /$ neutrophils to tiotropium bromide with and without carbachol acetylcholine, muscarin and oxotremorin we used the Kruskall-Wallis test, the Mann-Whitney rank-sum test and the Wilcoxon signed-rank test respectably, if appropriate. Statistical significance was accepted at the level of $p<0.05$. All statistical tests were performed using the SigmaStat software version (SPSS Science).

\section{Results}

Patient characteristics are shown in table 1.

\section{Chemotaxis}

Supernatant from AM stimulated with LPS (0.1, 1 and $10 \mu \mathrm{g} / \mathrm{ml}$ ) caused a concentration-dependent increase in the neutrophilic migration. A LPS concentration of $1 \mu \mathrm{g} / \mathrm{ml}$ resulted in an optimal chemotaxis, and was used in all consecutive experiments.

\section{Involvement of muscarinic receptors in LPS-mediated effects}

Supernatant from AM cultured with LPS and the anticholinergic drug tiotropium $(30 \mathrm{nM})$ resulted in a significant $(\mathrm{p}<0.001)$ reduction of neutrophil migration compared with supernatant from AM cultured with LPS alone (figure 1). Tiotropium had no effect on migration rates in the absence of LPS (data not shown). Taken together, these data suggest that

Table 1 Baseline parameters of patients (mean \pm SD)

\begin{tabular}{|c|c|}
\hline Parameter & Value \\
\hline $\mathrm{N}$ & 71 \\
\hline Women & $n=46(64.8 \%)$ \\
\hline Men & $n=25(35.2 \%)$ \\
\hline \multicolumn{2}{|c|}{ Lung function and blood gas analysis } \\
\hline FEV1 (\%predicted) & $80.3 \pm 23.1$ \\
\hline FEV/FVC (\%) & $69.1 \pm 7.6$ \\
\hline $\mathrm{pO} 2(\mathrm{mmHg})$ & $72.5 \pm 12.1$ \\
\hline $\mathrm{pCO} 2(\mathrm{mmHG})$ & $37.0 \pm 3.4$ \\
\hline $\mathrm{pH}$ & $7.4 \pm 0.01$ \\
\hline \multicolumn{2}{|c|}{ Cell differential of bronchoalveolar lavage } \\
\hline Alveolar macrophage [\%] & $91.1 \pm 7,2$ \\
\hline Neutrophils [\%] & $5.2 \pm 3,1$ \\
\hline Lymphocyte [\%] & $1.9 \pm 0,7$ \\
\hline Eosinophils [\%] & $0.7 \pm 0,4$ \\
\hline Mast cells [\%] & $0.1 \pm 0,3$ \\
\hline Total cells $\left[10^{6}\right]$ & $8.9 \pm 5,5$ \\
\hline
\end{tabular}

activation of muscarinic receptors was involved in the LPS-mediated release of chemotactic factors. To further investigate this point, co-incubation experiments with AChE (acetylcholinesterase) added to LPS stimulated AM cell medium $(n=9)$ resulted in reduced migration rates of neutrophils: $154 \% \pm 33 \%$ of control (LPS alone), $113 \% \pm 17 \%$ (LPS + AChE, p value $<0.001$ ), suggesting that acetylcholine release and consequent activation of muscarinic receptors are part of the signalling cascade activated by LPS.

To further explore this aspect, AM were stimulated with different muscarinic agonists, i.e. acetylcholine, carbachol, muscarin and oxotremorine. However, neither of these agonists induced neutrophilic migration alone, nor potentiated LPS-mediated effect $[+45.5 \pm 39.1 \%$ (LPS+ acetylcholine), $+12.3 \pm 12.7 \%$ (LPS + carbachol), $+15.2 \pm$ $19.8 \%$ (LPS+muscarin), $+21.2 \pm 17.1 \%$ (LPS+oxotremorine), $+41.5 \pm 23.2 \%$ (LPS)]. Taken together, these data suggest that $\mathrm{ACH}$ release and muscarinic receptor activation are a necessary component in LPS mediated effect, but not sufficient.

\section{Detection of which muscarinic receptor subtype is involved in LPS effects}

The analysis of muscarinic M1R, M2R and M3R mRNAs by RT-PCR showed that all the subtypes are present in AM, with muscarinic M3R mRNA transcripts dominating over M2R, and M1R (figure 2). $20 \mathrm{~h}$ after isolation from BAL, M-receptor expression increased compared with $2 \mathrm{~h}$ incubation $(\mathrm{p}<0.001)$. At the $20 \mathrm{~h}$ time point $\mathrm{M}$-receptor expressions did not vary regardless of stimulants added to the cell medium (figure 3).

The muscarinic M3R antagonist 4-diphenylacetoxy-Nmethylpiperidine methiodide (4-DAMP) and tiotropium

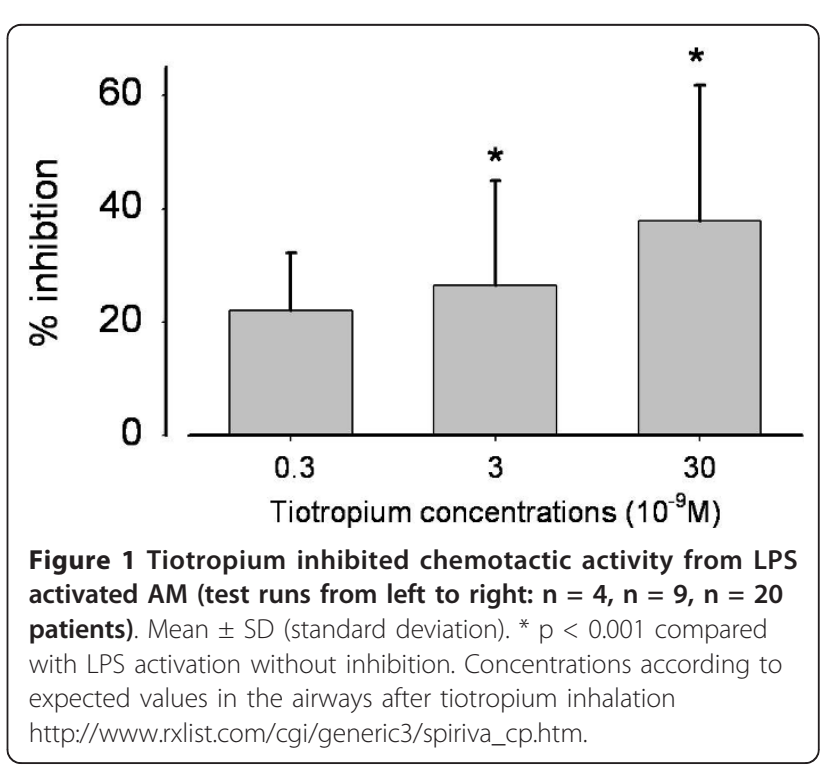




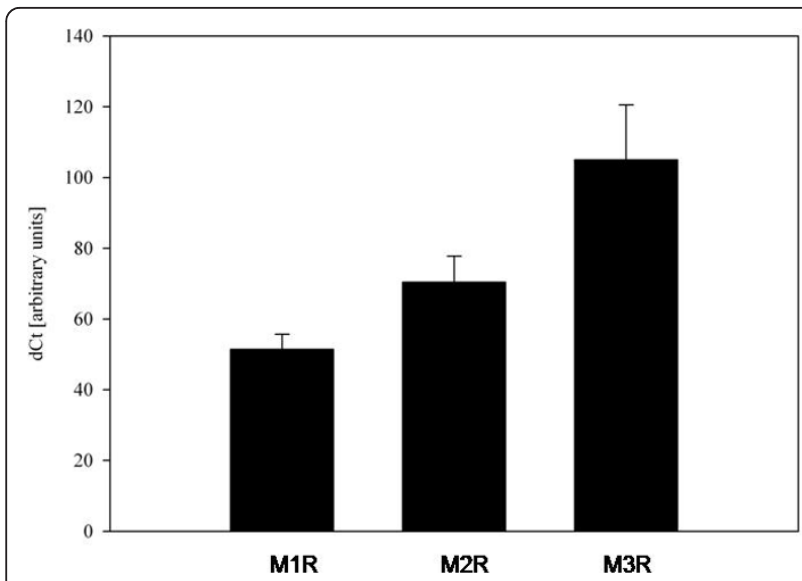

Figure 2 Cellular mRNA levels of muscarinic M1R (MRC1), M2R (MRC2), M3R (MRC3) subreceptors in alveolar macrophages from COPD patients $(n=11)$. Mean+SD.

( $\mathrm{p}<0.01$ vs. LPS stimulation alone) reduced neutrophilic migration rate in our chemotaxis system, whereas the muscarinic M1R-receptor antagonist pirenzepine and M2R antagonist gallamine did not (figure 4).

Taken together, these data suggest that, in this model, $\mathrm{ACh}$ exerts its activity through the activation of the human M3R, which is also the most expressed subtype in AM.

\section{Anticholinergic effects in reducing mediator release} As expected, LPS exposure of AM resulted in an increase of many pro inflammatory mediators, as TNFa, IL-8, IL-6, LTB4, GM-CSF and MIP $\alpha / \beta$ (data not shown). Coincubation with tiotropium $(30 \mathrm{nM})$ resulted in a significant reduction of elevated TNF $\alpha$ secretion from LPS stimulated AM, which correlated fairly with

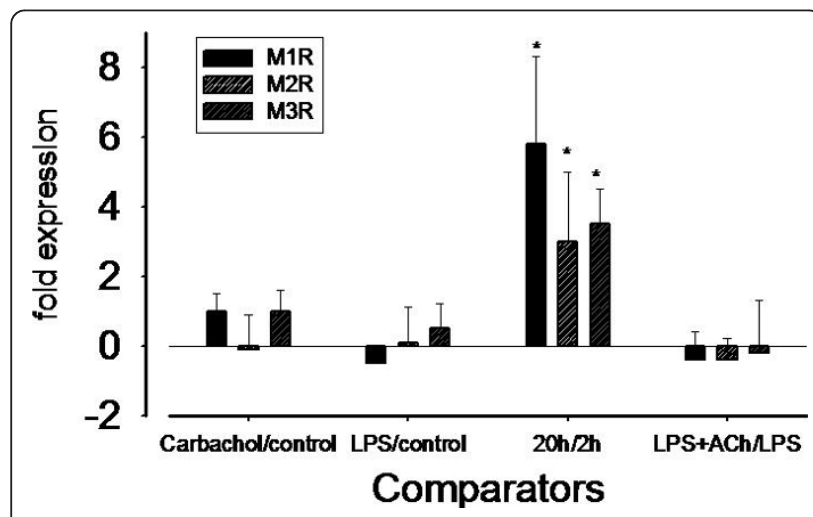

Figure 3 Differences in muscarinic receptor (MRC1-3) expression profile in AM from $n=19$ COPD patients depending on culture conditions. $X$-axis represents comparisons always after an incubation time of $20 \mathrm{~h}$ : carbachol vs. control, LPS vs. control, 20 h vs. 2 h, LPS + ACh vs. LPS. Mean \pm SD. ${ }^{*} p=<0.001$ (repeated measures One Way ANOVA).

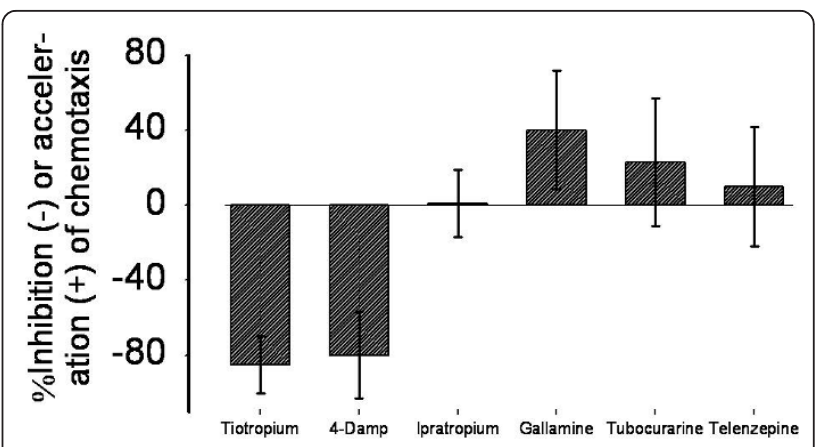

Figure 4 Inhibition of AM induced chemotactic activity from tiotropium on neutrophils is predominantly driven by M3Rblockage ( $\mathrm{n}=10$ ): Tiotropium $30 \mathrm{nM}$, 4-DAMP $100 \mathrm{nM}$ (each: $\mathrm{p}$ $<0.01$ vs. LPS stimulation alone), Ipratropium $30 \mathrm{nM}$, Gallamine $100 \mu \mathrm{M}$, Tubocurarine $100 \mu \mathrm{M}$, Telenzepine $10 \mathrm{nM}$. Doses were adapted from earlier studies and customized to our assay conditions $[43,63,64]$.

the reduction of neutrophil migration rates $\left(R^{2}=0.335\right.$, $p<0.001$, figure 5). Concerning the other cytokines, tiotropium had no significant effect (date not shown).

\section{Release of reactive oxygen species in AM}

ROS are another important pro-inflammatory stimulus in COPD which is known to be a chemotactic factor. We therefore tested tiotropium bromide also to reduce ROS in order to further elucidate anti-inflammatory efficacy of this compound. Among the different stimuli tested, PMA $(0.1 \mu \mathrm{g} / \mathrm{ml})$ generated the highest ROS release in cultured AM, followed by LPS, which in turn is a stronger stimulus than carbachol. As expected, dexametasone $(10 \mu \mathrm{M})$, which was used as positive control, substantially reduced LPS mediated ROS (figure 6). In 11 out of 16 patients tiotropium $(30 \mathrm{nM})$ reduced ROS production from LPS stimulated AM by $36.1 \%$. After

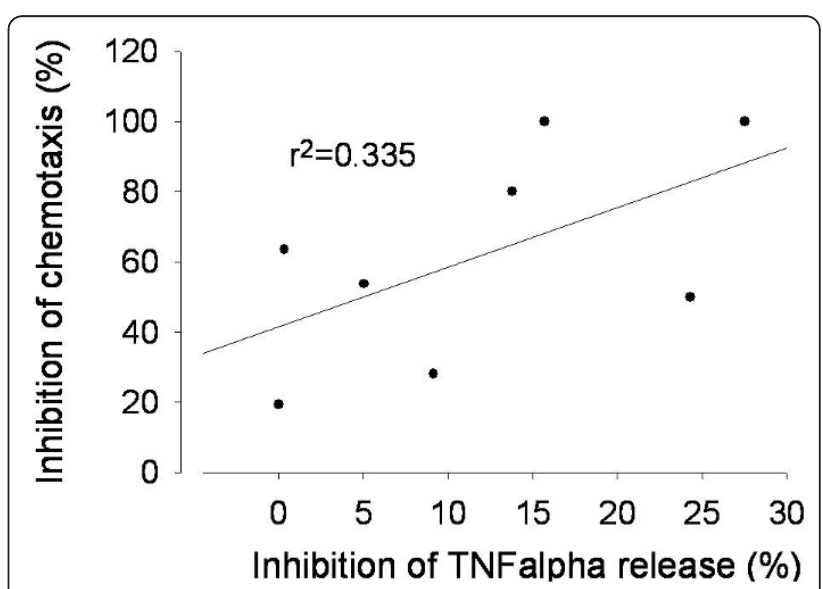

Figure 5 Correlation of TNF $\alpha$ release of pre-cultured and LPS activated alveolar macrophages (AM) to the migration rate of neutrophils cultured with AM cell medium (Tiotropium $30 \mathrm{nM}$ ). 


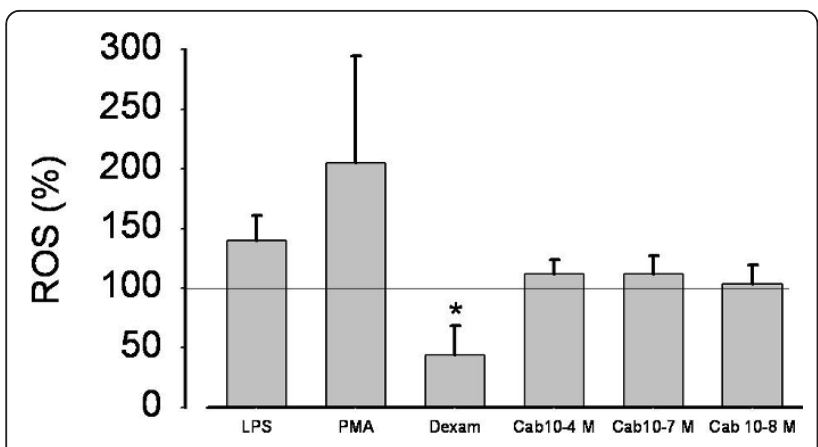

Figure 6 ROS (reactive oxygen species) release from LPS, PMA or carbachol activated alveolar macrophages (AM) from 16 patients. ROS production in unstimulated cells was defined as $100 \%$, ROS in cell free medium was 0. LPS $1 \mu \mathrm{g} / \mathrm{ml}$; Carb =

carbachol in various concentrations; Dexam = Dexametasone $10^{-7} \mathrm{M}$ in LPS activated AM; PMA $0.1 \mu \mathrm{g} / \mathrm{ml}$. Data expressed as mean \pm SD. ${ }^{*} p<0.001$ vs. LPS.

stimulation with carbachol $(100 \mu \mathrm{M})$, tiotropium induced a $46.2 \%$ reduction in ROS release; ( $p<0.001$ vs. LPS or carbachol alone; figure 7).

\section{Discussion}

Clinical studies in COPD patients using inhaled anticholinergic tiotropium $18 \mu \mathrm{g}$ once daily revealed reduced exacerbation rates as well as an improvement of lung function and the natural course of COPD [28,29]. The underlying mechanism how long-term treatment with tiotropium prevents exacerbations in these patients is unclear since the drug is regarded as a bronchodilator apparently lacking antiinflammatory capabilities in vivo $[30,31]$. COPD exacerbations are at the cellular level characterized by increasing systemic and bronchial inflammation which can be at least in part influenced by long-term treatment of inhaled corticosteroids [32-36]. It is unlikely that pure bronchodilation may cause this phenomenon because long-acting $\beta 2$-agonist therapy

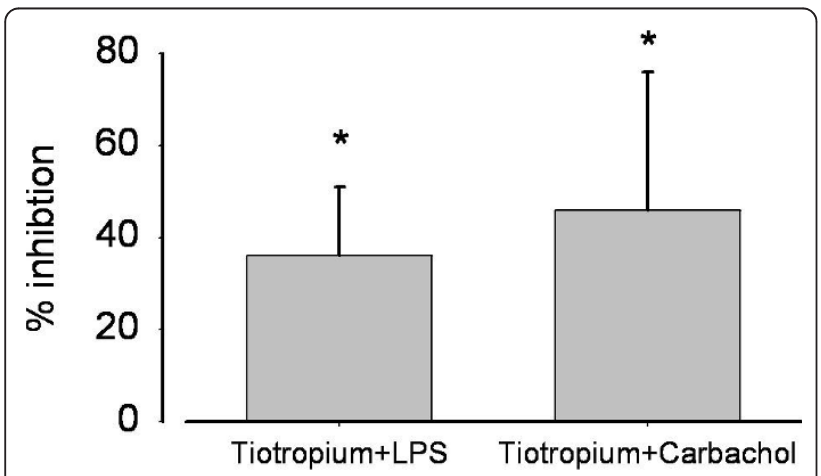

Figure 7 Inhibition of ROS release by tiotropium $\left(3 \times 10^{9} \mathrm{M}\right)$ in LPS $(1 \mu \mathrm{g} / \mathrm{ml})$ or carbachol $\left(10^{-4} \mathrm{M}\right)$ activated alveolar macrophages. ${ }^{*} p<0.001$, both comparisons with LPS or carbachol alone. Mean \pm SD. alone is unable to reduce exacerbation rates and exacerbation severity to a clinically meaningful extent [37-39].

COPD has a high driving force to recruit inflammatory cells from the capillary bed into the airways [40] which is at least in part regulated by the muscarinic cholinergic system $[41,42]$. The ACh promoting effect on neutrophilic migration rate is dose dependent as Sato et al were able to demonstrate in ACh $(1-100 \mu \mathrm{M})$ activated bovine alveolar macrophages [43]. In concordance with other studies, our data demonstrate a) that ACh drives chemotaxis since AChE reduces LPSinduced neutrophilc migration rates by about $40 \%$, and b) that long-acting muscarinic receptor antagonist tiotropium bromide has additional anti-inflammatory capabilities due to reducing chemotactic activity of cultured $\mathrm{AM}$ in vitro. In regard to chemotaxis induction, ACh proved to be a much weaker driving force than LPS, suggesting that its role in LPS-mediated effects is necessary, but not sufficient to induce migration. Also, exogenously added ACh did not further enhance LPS efficacy, suggesting that LPS is per se already very efficacious and maximal chemotaxis was already reached (ceiling effect). Because of that, we run our experiments solely with LPS. In our experimental setup tiotropium bromide reduced LPS-mediated chemotaxis, possibly through an antiinflammatory effect as indicated by the reduction of TNF $\alpha$ release. Anti-inflammatory drugs, such as phosphodiesterase 4 inhibitors, have been shown to reduce TNF $\alpha$ and chemotaxis in sputum of COPD patients [44] which is at least in part mediated by mitogen activated protein (MAP) kinase pathway [45]. Our data may point to a similar effect of tiotropium bromide. However, TNF $\alpha$ reduction correlated weakly with the drop of chemotaxis, hinting that other mechanisms may be involved in tiotropium bromide influence in human alveolar macrophage/neutrophil chemotaxis. Because the supernatant used in the chemotaxis chamber contained tiotropium it might have exerted an additional effect on neutrophils which also express muscarinic receptors [14].

Surprisingly, tiotropium bromide failed to have any impact on the chemotactic mediators IL8, IL6, LTB4 and GM-CSF but not on cellular ROS release. Various other studies in myocytes also emphasize the stimulating effect of ACh on ROS production which is caused by activation of PI3K, Src-kinases or the ERK pathway at last leading to opening of mitochondrial $\mathrm{K}^{\mathrm{ATP}}$ channels and ROS release $[46,47]$. ROS by themselves trigger chemokine production in inflammatory cells thus enhancing the inflammatory process $[48,49]$. The involvement of the cholinergic system in ROS and ROS-mediated cytotoxicity make it an ideal system to test muscarinic receptor inhibitors for their cell protective function. In this context we were able to demonstrate that 
nanomolar concentrations of tiotropium protect cells by reducing the oxidant load produced by alveolar macrophages and LPS-mediated cytotoxicity. The concentration needed to obtain the cell protective effect in our cytotoxicity assay is in a physiologic range which can be achieved in human airways after inhalation. However, best protection was seen at high concentrations (300 nmolar). Possibly, reduction of ROS release is another mechanism by which tiotropium bromide limits chemotaxis. Our data are in good concordance with Wollin and Pieper describing a dose-dependent reduction of pulmonary neutrophilic inflammation of inhaled tiotropium $(0.01-0.3 \mathrm{mg} / \mathrm{ml})$ in smoke exposed mice [50], but they seem to defy Perng et al. [31], who didn't detect any antiinflammatory effect of tiotropium in humans. The difference between the three studies may be due to the lack of a placebo arm in the COPD trial in which all 3 treatment arms (fluticasone/sameterol, fluticasone/tiotropium, tiotropium alone) failed to show differences in the cellular component in sputum although differences in some inflammatory mediators were observed.

Profita et al. (2008) demonstrated in 16HBE cells that acetylcholine-mediated IL-8 release significantly increased chemotaxis of neutrophils. This effect was inhibited by tiotropium bromide [51]. In the A549 and MonoMac6 cell line as well as in alveolar macrophages derived from non-smoking patients without a pulmonary disease tiotropium bromide decreased the release of chemotactic mediators after stimulation with high doses of ACh $(100 \mu \mathrm{M})$ by about $70 \%$ [14]. Because ACh did not influence cellular release of IL-8 and monocyte chemotactic protein-1 (MCP-1) the authors suggested that leukotriene B4 (LTB4) was the driving force of chemotactic activity.

However, the authors failed to clearly demonstrate that the reducing effects of tiotropium bromide correlate with inhibition of cellular LTB4 release. Nevertheless there is clear relationship between ACh mediated LTB4 release and chemotaxis of inflammatory cells in COPD patients, who have higher LTB4 amounts in induced sputum, which correlates with number of sputum neutrophils, than healthy volunteers. ACh $(100 \mu \mathrm{M})$ stimulated sputum cells from COPD patients but not from non-smokers release LTB4. Also in blood monocytes LTB4-production was ACh sensitive. These effects could be blocked by an inhibitor of extra cellular signal-regulated kinase, but also by the anticholinergic compound oxitropium bromide at a concentration of $10 \mu \mathrm{M}$ [52]. However, this drug concentration is high when taking into account that by inhalation only nanomolar concentrations can be achieved locally http://www.rxlist.com/ cgi/generic3/spiriva_cp.htm. The reason why we failed to demonstrate an inhibitory effect of tiotropium bromide on IL8 or LTB4 release from AM may be dependent on the chosen cells, since we evaluated human AM and human neutrophils instead of using a cell line. Because of working with primary cells, we think that our model is more representative of the situation in the airways of COPD patients.

It seems reasonable that M-receptor blockage inhibits chemotaxis, reduces anti-proliferative effects and ROS release, since activation of the cholinergic system has been shown a) to induce proliferative processes in airway tissue in vitro [53] as well as in vivo $[16,19]$, b) to induce eosinophilic chemotactic activity $[43,54]$, and c) ACh potentates the release of pro-inflammatory 15-HETE and prostaglandin E2 [55]. Further, cell proliferation of fibroblasts and myofibroblasts could be blocked by the nicotinic antagonist $n$-tubocurarine and antimuscarinic compounds [17,53], and progression of airway smooth muscle remodeling in a allergen challenge asthma model could be minimized using tiotropium bromide [16].

M1R, M2R and M3R mRNAs were all present in AM. M3R mRNA transcripts dominate over M2R, and $\mathrm{M} 1 \mathrm{R}$ and expression increased $20 \mathrm{~h}$ compared with the beginning. We could confirm previous studies also showing muscarinic receptor expression in cell cultures. Differences in the extent of mRNA transcript levels are most likely related to different cell types [51] or different experimental set up and patient characteristics [52].

Our study has some shortcomings. First, although 71 patients were recruited, the number of single measurements of each assay block was low, which was due to the numerous controls and limited cell number per patient. However, due to strict selection criteria, data from the different experimental settings still are comparable. Second, due to numerous controls, number of single measurements seems low, and would have otherwise resulted in better statistics. This relates in particular to the weak $\mathrm{TNF} \alpha /$ chemotaxis correlation. Third, in only about $50 \%$ of the cytotoxicity and ROS experiments in which the various inhibitors were tested, tiotropium bromide revealed inhibitory efficacy. This observation is not unique for our work since it has been found also in other studies on this subject. Blaas et al stimulated primary epithelial lung cells with carbachol $(100 \mu \mathrm{g} / \mathrm{ml})$ and found only in 5 out of 12 patients enhanced IL-8 release. In their experiments neutrophilic migration could be induced by carbachol in about $40 \%$ of their patients [56]. Subject variability $[57,58]$, health status, varying nicotine consumption [59], cell type [60] and species differences $[61,62]$ may be confounding factors contributing to this phenomenon. Forth, the number of migrated cells in our chemotaxis chamber system seems low in 
comparison to other publications. To detect more objectively migrated neutrophils and in order to enable high output measurements we used a fairly new chemotaxis chamber detecting fluorescence as the cellular marker for leukocyte migration. Other papers simply count the cells by light microscopy in the adjacent chamber as well as the filter whereas our system only detects truly migrated cells disregarding those cells sticking in the filter. Our assay has been described to comprise significant advances quantifying leukocyte chemotaxis and explains the differences to previous publications [26].

\section{Conclusion}

Our results show that tiotropium bromide inhibits AM mediated chemotaxis of neutrophils. This effect correlates at least in part by concomitant TNF $\alpha$ reduction. Further, it reduces cellular proinflammatory activities such as the generation of ROS. Experiments with selective $M$-receptor inhibitors indicate that the M3R subtype is responsible for tiotropium bromide inhibition of chemotaxis.

\section{Funding}

This study was funded by Boehringer Ingelheim $\mathrm{GmbH}$, Germany.

\section{Acknowledgements \\ The authors appreciate the help of Katharina Dück and Ramona Dück who supported us regarding the set up of the experiments, the collection of clinical data and general assistance. \\ Author details \\ ${ }^{1}$ Robert-Koch-Hospital, St. George Medical Center, Leipzig, Germany. ${ }^{2}$ Department for Pulmonary Medicine, Allergology, Sleep Medicine and Intensive Care, Hospital Bethanien, Universitaet Witten/Herdecke, Solingen, Germany. ${ }^{3}$ Department of Pulmonary Medicine, General Hospital, Kassel, Germany.}

\section{Authors' contributions}

All authors have made substantial contributions. GV established the assays, and coordinated the work in the laboratory. She carried out the molecular genetic studies as well the immunoassays GV wrote the first version of the manuscript. WR helped in revising the manuscript critically for important intellectual content. AG planed the conception and design of the study and applied for the funding. He recruited the patients, collected the clinical data, wrote the final version of the manuscript and gave final approval of the version to be published. All authors read and approved the final manuscript.

\section{Competing interests}

GV declares that she has no competing interests. WG and AG have received consulting fees, speaking fees, and grant support from Boehringer Ingelheim Pharma Germany.

Received: 9 December 2009 Accepted: 27 February 2011

Published: 27 February 2011

\section{References}

1. Saetta M: Airway inflammation in chronic obstructive pulmonary disease. Am J Respir Crit Care Med 1999, 160:S17-S20.
2. Saetta M, Finkelstein R, Cosio MG: Morphological and cellular basis for airflow limitation in smokers. Eur Respir J 1994, 7:1505-1515.

3. Keatings VM, Barnes PJ: Granulocyte activation markers in induced sputum: comparison between chronic obstructive pulmonary disease, asthma andnormal subjects. Am J Respir Crit Care Med 1997, 155:449-453

4. O'Donnell RA, Peebles C, Ward JA, Daraker A, Angco G, Broberg P, Pierrou S, Lund L, Holgate ST, Davies DE, et al: Relationship between peripheral airway dysfunction, airway obstruction, and neutrophilic inflammation in COPD. Thorax 2004, 59:837-842.

5. Beeh KM, Kornmann O, Buhl R, Culpitt SV, Giembycz MA, Barnes PJ: Neutrophil chemotactic activity of sputum from patients with COPD: Role ofinterleukin 8 and leukotriene B4. Chest 2003, 123:1240-1247.

6. Traves SL, Culpitt SV, Russell RE, Barnes PJ, Donnelly LE: Increased levels of the chemokines GROa and MCP-1 in sputum samples from patients with COPD. Thorax 2002, 57:590-510.

7. Mikami M, Llewellyn-Jones CG, Bayley DL, Hill SL, Stockley RA: The chemotactic activity of sputum from patients with bronchiectasis. Am J Physiol 1998, 264:L413-L418.

8. Hogg JC: Pathophysiology of airflow limitation in chronic obstructive pulmonary disease. Lancet 2004, 364:709-721.

9. Chung KF: Cytokines as targets in chronic obstructive pulmonary disease. Curr Drug Targets 2006, 7:675-681.

10. Beeh KM, Beier J: Handle with care: targeting neutrophils in chronic obstructive pulmonary disease and severe asthma? Clin Exp Allergy 2006, 36:142-157.

11. Gizycki MJ, Hattotuwa KL, Barnes N, Jeffery PK: Effects of fluticasone propionate on inflammatory cells in COPD: an ultrastructural examination of endobronchial biopsy tissue. Thorax 2002, 57:799-803.

12. Hattotuwa KL, Gizycki MJ, Ansari TW, Jeffery PK, Barnes NC: The effect of inhaled fluticasone on airway inflammation in chronic obstructive pulmonary disease: a double-blind, placebo-controlled biopsy study. Am J Respir Crit Care Med 2002, 165:1592-1596.

13. Boorsma M, Lutter P, Pol van de MA, Out TA, Jansen HM, Jonkers RE: Longterm effects of budesonide on inflammatory status in COPD. COPD: Journal of Chronic Obstructive Pulmonary Disease 2008, 5:97-104.

14. Bühling F, Lieder N, Kühlmann UC, Waldburg N, Welte T: Tiotropium suppresses acetylcholine-induced release of chemotactic mediators in vitro. Respir Med 2007, 101:2386-2394.

15. Bos IS, Gosens R, Zuidhof AB, Schaafsma D, Halayko AJ, Meurs H, Zaagsma J: Inhibition of allergen-induced airway remodelling by tiotropium and budesonide: a comparision. Eur Respir J 2007, 30:653-661.

16. Gosens R, Bos ST, Zaagsma J, Meurs H: Protective effects of tiotropium bromide in the progresse of airway smooth muscle remodeling. Am J Respir Crit Care Med 2005, 171:1096-1102.

17. Pieper MP, Chaudhary NI, Park JE: Acetylcholine-induced proliferation of fibroblasts and myofibroblasts in vitro is inhibited by tiotropium bromide. Life Sci 2007, 80:2270-2273.

18. Racké K, Haag S, Bahulayan A, Warnken M: Pulmonary fibroblasts, an emerging target for anti-obstructive drugs. Naunyn-Schmiedeberg's Arch Pharmacol 2008, 378:193-201.

19. Gosens R, Nelemans A, Groote Bromhaar MM, McKay S, Zaagsma J, Meurs H: Muscarinic M3-receptors mediate cholinergic synergism of mitogenesis in airway smooth muscle. Am J Respir Crit Care Med 2003, 28:257-262.

20. GOLD Executive Committee: Global initiative for chronic obstructive lung disease. www goldcopd com 2007.

21. Haslam PL, Baughman RP: Report of ERS Task Force: guideline for measurement of acellular components and standardization of BAL. Eur Respir J 1999, 14:245-248.

22. Report of the European Society of pneumology task group on BAL: Technical recommendations and guidelines for bronchalveolar lavage (BAL). Eur Respir J 1989, 2:561-585.

23. Repetto $G$, del Peso A, Zurita JL: Neutral red uptake assay for the estimation of cell viability/cytotoxicity. Nat Protoc 2008, 3:1125-1131.

24. Hammond ME, Lapointe GR, Feucht PH, Hilt S, Galleqos CA, Gordon CA Giedlin MA, Mullenbach G, Tekamp-Olson P: IL-8 induced neutrophil chemotaxis predominantly via type I IL-8 receptors. J Immunol 1995, 155:1428-1433.

25. Quan JM, Martin TR, Rosenberg GB, Foster DC, Whitemore T, Goodman RB: Antibodies against the N-terminus of IL-8 receptor A inhibit neutrophil chemotaxis. Biochem Biophys Res Commun 1996, 219:405-411. 
26. Frevert CW, Wong VA, Goodman RB, Goodwin R, Martin TR: Rapid fluorescence-based measurements of neutrophil migration in vitro. J Immunol Meth 1998, 213:41-52.

27. Barbieri SS, Eligini S, Brambilla M, Tremoli E, Colli S: Reactive oxygen species mediate cyclooxygenase-2 induction during monocyte to macrophage differentiation: critical role of NADPH oxidase. Cardiovasc Res 2003, 60:187-197.

28. Dusser $D$, Bravo ML, lacono P: The effect of tiotropium on exacerbations and airflow in patients with COPD. Eur Respir J 2006, 27:547-555.

29. Tashkin DP, Celli BR, Senn S, Burkhart D, Kesten S, Menjoge SS, Decramer M: A 4-year trial of tiotropium in chronic obstructive pulmonary disease. $\mathrm{N}$ Engl J Med 2008, 359:1543-1554.

30. Powrie DJ, Wilkinson TM, Donaldson GC, Jones PW, Scrine K, Viel K, Kesten S, Wedzicha JA: Effect of tiotropium on sputum and serum inflammatory markers and exacerbations in COPD. Eur Respir J 2007, 30:472-478.

31. Perng D-W, Tao CW, Su K-C, Tsai C-C, Liu L-Y, Lee Y-C: Anti-inflammatory effects of salmeterol/fluticasone, tiotropium/fluticasone or tiotropium in COPD. Eur Respir J 2009, 38:778-784

32. Groenewegen KH, Postma DS, Hop WC, Wielders PLML, Schlösser NJJ, Wouters EFM: Increased systemic inflammation is a risk factor for COPD exacerbations. Chest 2008, 133:350-357.

33. Burge PS, Calverley PMA, Jones PW, Anderson JA, Maslen TK: Randomised, double blind, placebo controlled study of fluticasone propionate in patients with moderate to severe chronic obstructiv pulmonary disease: the ISOLDE trial. BMJ 2000, 320:1297-1303.

34. Wouters EF, Postma DS, Fokkens B, Hop WC, Prins J, Kuipers AF, Pasma HR, Hensing CA, Creutzberg EC: Withdrawal of fluticasone propionate from combined salmeterol/fluticasone treatment in patients with COPD cause immediate and sustained disease deterioation: a randomised controlled trial. Thorax 2005, 60:480-487

35. Jones PW, Willits LR, Burge PS, Calverley PMA: Disease severity and the effect of fluticasone propionate on chronic obstructive pulmonary diasase exacerbations. Eur Respir J 2003, 21:68-73.

36. Vestbo J, Sørensen T, Lange P, Brix A, Torre P, Viskum K: Long-term effect of inhaled budesonide in mild and moderate chronic obstructive pulmonary disease: a randomised controlled trial. Lancet 1999, 355:1819-1823.

37. Calverley PMA, Anderson JA, Celli BR, Ferguson GT, Jenkins C, Jones PW, Yates J, Vestbo J: Salmeterol and fluticasone propionate and survival in chronic obstructive pulmonary disease. N Engl J Med 2007, 356:775-789.

38. National Institute for Clinical Excellence: Chronic obstructive pulmonary disase. National clinical guideline on management of chronic obstructive pulmonary disease in adults in primary and secondary care. Thorax 2004, 59:1-232.

39. Szafranski W, Ramirez A, Menga G, Sansores R, Nahabedian S, Peterson S, Olsson $\mathrm{H}$ : Efficacy and safety of budesonide/formoterol in the management of chronic obstructive pulmonary disease. Eur Respir J 2003, 21:74-81.

40. Balbi B: COPD, is chemotaxis the key ? Chest 2003, 123:983-986.

41. Wessler IK, Kirkpatrick J: The non-neuronal cholinergic system: an emerging drug target in the airways. Pulm Phamacol Therapeutics 2001, 14:423-434.

42. Groneberg DA, Quarcoo D, Frossard N, Fischer A: Neurogenic mechanisms in bronchial inflammatory diseases. Allergy 2004, 59:1139-1152.

43. Sato E, Koyama S, Okubo Y, Kubo K, Sekiguchi M: Acetylcholine stimulates alveolar macrophages to release inflammatory cell chemotactic activity. Am J Physiol (Lung Cell Mol Physiol) 1998, 18:L970-L979.

44. Profita M, Chiappara G, Mirabella F, Di Giorgi R, Chimenti L, Costanzo G, Bellia $V$, Bousquet J, Vignola AM: Effect of cilomilast (Ariflo) on TNF-alpha, IL-8, and GM-CSF release by airway cells of patients with COPD. Thorax 2003, 58:573-579.

45. Drost $\mathrm{E}$, MacNee W: Potential role of IL-8, platelet-activating factor and TNF-alpha in the sequestration of neutrophils in the lung: effects on neutrophil deformability, adhesion receptor expression, and chemotaxis. Eur J Immunol 2002, 32:393-403.

46. Samavati L, Monick MM, Sanlioglu S, Buettner GR, Oberley LW, Hunninghake GW: Mitochondrial K ${ }^{\text {ATP }}$ channel openers activate the ERK kinase by an oxidant-dependent mechanism. Am J Physiol Cell Physiol 2002, 283:C273-C281.
47. Oldenburg O, Critz SD, Cohne MV, Downey JM: Acetylcholine-induced production of reactive oxygen species in adult rabbit ventricular myocytes is dependent on phosphatidylinositol and Src-kinaseactivation and mitochondrial K ${ }^{\text {ATP }}$ channel opening. J Mol Cell Cardiol 2003, 35:653-660.

48. Barret EG, Johnston C, Oberdorster G, Finkelstein JN: Silica-induced chemokine expression in alveolar type II cells is mediated by TNF alfa induced oxidant stress. Am J Physiol Lung Cell Mol Physiol 1999, 276: L979-L988.

49. De Keulenaer GW, Ushio-Fukai M, Yin Q, Chung AB, Lyons PR, Ishizaka N, Rengarajan K, Taylor WR, Alexander RW, Griendling KK: Convergence of redox-sensitive and mitogen-activated protein kinase signaling pathways in tumor necrosis factor-alpha-mediated monocyte chemoatractant protein-1 induction in vascular smooth muscle cells. Arteriscler Throm Vasc Biol 2000, 20:385-391.

50. Wollin L, Pieper MP: Tiotropium bromide exerts anti-inflammatory activity in a cigarette smoke mouse model of COPD [abstract]. Am J Respir Crit Care Med 2009, 179:A6196.

51. Profita M, Bonanno A, Siena L, Ferraro M, Montalbano AM, Pompeo F, Riccobono L, Pieper MP, Gjomarkaj M: Acetylcholine mediates the release of IL-8 in human bronchial epithelial cells by a NFkB/ERK-dependent mechanism. Eur J Pharmacol 2008, 582:145-153.

52. Profita M, Di Giorgi R, Sala A, Bonanno A, Riccobono L, Mirabella F, Gjomarkaj M, Bonsignore G, Bousquet J, Vignola AM: Muscarinic receptors, leukotriene B4 production andneutrophilic inflammation in COPD patients. Allergy 2005, 60:1361-1369.

53. Metzen J, Bittinger F, Kirkpatrick J, Kilbinger $H$, Wessler IK: Proliferative effect of acetylcholine on rat trachea epithelial cells is mediated by nicotinic receptors and muscarinic receptors of the M1-subtype. Life Sci 2003, 72:2075-2080.

54. Koyama S, Sato E, Nomura H, Kubo K, Nagai S, Izumi T: Acetylcholine and substance $\mathrm{P}$ stimulate bronchial epithelial cells to release eosinophilic chemotactic activity. J Appl Physiol 1998, 84:1528-1534.

55. Salari $H$, Chan-Yeung M: Release of 15-hydroxyeicosatetraenoic acid (15-HETE) and prostaglandin E2 (PGE2) by cultured human bronchial epithelial cells. Am J Respir Cell Mol Biol 1989, 1:245-250.

56. Blaas SH, Schulz C, Stoelcker B, Wacker M, Ruhland B, Pfeifer M: Carbachol induced proinflammatory cytokine release from primary bronchial epithelial cells [abstract]. Am J Respir Crit Care Med 2007, 175:A178.

57. Sato KZ, Fujii T, Watanabe Y, Yamada S, Ando T, Kazuko F, Kawashima K: Diversity of mRNA expression for muscarinic acetylcholine receptor subtypes and neuronal nicotinic acetylcholine receptor subunits in human mononuclear leukocytes and leukemic cell lines. Neurosci Lett 1999, 266:17-20.

58. Bany U, Ryzewski J, Maslinski W: Relative amounts of mRNA encoding four subtypes of muscarinic receptors (M2-M5) in human peripheral blood mononuclear cells. J Neuroimmunol 1999, 97:191-195.

59. Gahring LC, Rogers SW: Neuronal nicotinic acetylcholine receptor expression and function on nonneuronal cells. AAPS J 2006, 7:E885-94

60. Meurs H, Timmermans A, de Monchy JG, Zaagsma J, Kauffman H: Lack of coupling of muscarinic receptors to phosphoinositide metabolism and adenylyl cyclase in human lymphocytes and polymorphonuclear leukocytes: studies in healthy subjects and allergic asthmatic patients. Int Arch Allergy Immunol 1993, 100:19-27.

61. Gwilt CR, Donnelly LE, Rogers DF: The non-neuronal cholinergic system in the airways: an unappreciated regulatory role in pulmonary inflammation? Pharmacol Ther 2007, 115:208-222.

62. Matsunaga K, Kleine TW, Friedman B, Yamamoto Y: Involvement of nicotinic acetylcholine receptors in suppression of antimicrobial activity and cytokine responses of alveolar macrophages to Legionella pneumophila infection by nicotine. J Immunol 2001, 167:6518-6524.

63. Roffel AF, Elzinga CR, Zaagsma J: Muscarinic M3 receptors mediated contraction of human central and peripheral airway smooth muscle. Pulm Pharmacol 1990, 3:47-51.

64. Roffel AF, Elzinga CR, Amsterdam van RG, de Zeeuw RA, Zaagsma J: Muscarinic M2 receptor in bovine tracheal smooth muscle: discrepancies between binding and function. Eur J Pharmacol 1988, 153:73-82.

doi:10.1186/1465-9921-12-24

Cite this article as: Vacca et al:: Inhibition of granulocyte migration by tiotropium bromide. Respiratory Research 2011 12:24. 